\title{
50. PALEOBIOGEOGRAPHIC EVOLUTION OF SHALLOW-WATER ORGANISMS FROM THE APTIAN TO THE EOCENE IN THE WESTERN PACIFIC ${ }^{1}$
}

\author{
Isabella Premoli Silva, ${ }^{2}$ Alda Nicora, ${ }^{2}$ Annie Arnaud Vanneau, ${ }^{3}$ Ann F. Budd, ${ }^{4}$ Gilbert F. Camoin, ${ }^{5}$ and Jean-Pierre Masse ${ }^{5}$
}

\begin{abstract}
Shallow-water organisms recovered from drilling four guyots in the western Pacific (from the southern Marshall Islands to the Japanese Seamounts) allow the recognition of changes in bioprovinces through time. The Tethyan low-latitude bioprovince characterizes the early Aptian worldwide. In the late Albian, however, shallow-water floral and faunal assemblages from the drilled guyots, although predominantly composed of cosmopolitan forms, yielded few elements with an areal distribution more restricted to either the Caribbean-central American region or the Mediterranean, suggesting that two bioprovinces had already differentiated at low latitude at that time. During the late Campanian-Maastrichtian, the guyots' area was under the influence of the Caribbean bioprovince, but foraminifer assemblages also include some Mediterranean elements, suggesting that colonization occurred both westward and eastward. In the latest Paleocene-early middle Eocene, the direction of colonization reversed, with prevalent migration from the Mediterranean toward the Pacific.
\end{abstract}

\section{INTRODUCTION}

One of the objectives of Ocean Drilling Program (ODP) Legs 143 and 144 in the western Pacific was to recover shallow-water carbonate platform sediments from several guyots in two transects roughly oriented east-west (Mid-Pacific Mountains) and south-north (Marshall Islands to Japanese group) so that we could establish the evolutionary patterns of carbonate sedimentation and reconstruct the biogeographic evolution of the fossil assemblages. The aim of this paper is the preliminary analysis of Aptian to Eocene shallow-water organism paleobiogeography based on the specimens recovered from four out of five guyots drilled during Leg 144 along the south-north transect (Sites 871 through 879) (Premoli Silva, Haggerty, Rack, et al., 1993; see site map preceding title page). Primarily mid-Cretaceous shallow-water sediments were recovered at Allison and Resolution guyots during Leg 143, along with a small large-foraminifer fauna of late Campanian age from Site 869 (south of Wodejebato, Marshall Islands) (Sager, Winterer, Firth, et al., 1993). The overall midCretaceous faunal and floral assemblages from both legs are discussed by Arnaud Vanneau and Sliter (1994, 1995; also unpubl. data), whereas the upper Campanian fauna from Site 869 (Leg 143) is incorporated in the present discussion of the Marshall Islands assemblages.

Before Leg 144, the fossil record of shallow-water organisms in the western Pacific was confined to dredge-haul samples from few guyots or allochthonous material resedimented in deep-sea sites (e.g., Premoli Silva and Brusa, 1981; Grötsch et al., 1993; Lincoln et al., 1993; and references herein).

\section{FAUNAL AND FLORAL ASSEMBLAGES}

Shallow-water faunal and floral assemblages recovered during Leg 144 belong to three different ages: (1) Aptian-Albian (Site 878, MIT Guyot; and Site 879, Takuyo-Daisan Guyot) (for species descriptions

\footnotetext{
${ }^{1}$ Haggerty, J.A., Premoli Silva, I., Rack, F., and McNutt, M.K. (Eds.), 1995. Proc. ODP, Sci. Results, 144: College Station, TX (Ocean Drilling Program).

${ }^{2}$ Dipartimento di Scienze della Terra, Università di Milano, via Mangiagalli 34, 20133 Milano, Italy.

${ }^{3}$ Institut Dolomieu, Université de Grenoble, rue Maurice Gignoux, 30031 Grenoble Cedex, France.

${ }^{4}$ Department of Geology, The University of Iowa, 121 Trowbridge Hall, Iowa City, Iowa 52242-1379, U.S.A.

${ }^{5}$ Centre de Sédimentologie et Paléontologie, U.R.A. 1208 du CNRS, Université de Provence, 3 place Victor Hugo, F-13331 Marseille cedex 3, France.
}

and biostratigraphy, see Arnaud Vanneau and Premoli Silva, this volume, and Masse and Arnaud Vanneau, this volume); (2) late Campanian-Maastrichtian (Sites 873 through 877, Wodejebato Guyot) (for species descriptions and biostratigraphy, see Premoli Silva et al., this volume); and latest Paleocene-early middle Eocene (Site 871, Limalok Guyot) (for species descriptions and biostratigraphy, see Nicora et al., this volume). The most abundant and consistent fossil group from all ages is that of the larger benthic foraminifers. Subordinate fossil groups are rudists, corals, calcareous algae, and other bivalves and bryozoans. Estimated abundances of the various fossil groups are reported in the specialty chapters of this volume.

\section{Aptian-Albian Assemblages}

Almost $700 \mathrm{~m}$ of lower Aptian-upper Albian carbonate platform sediments were recovered at MIT Guyot (Site 878), and $170 \mathrm{~m}$, of late Aptian-late Albian age at Takuyo-Daisan Guyot (Site 879). Fourteen benthic foraminifer species, 17 species of calcareous algae, and 10 coral genera were identified altogether from the two sites (see Arnaud Vanneau and Premoli Silva, this volume, and Appendix, this chapter). The benthic foraminifer fauna is composed of common Vercorsella, Cuneolina, Orbitolina, Nezzazata, Voloshinoides?, less common trocholinids, Arenobulimina, Coskinolinella, miliolids, and other small foraminifers. Calcareous algal assemblages are dominated by the dasycladaceans, although the most consistent species is the red alga Polystrata alba (Masse and Arnaud Vanneau, this volume).

According to Arnaud Vanneau and Premoli Silva (this volume), seven biostratigraphic assemblages can be distinguished, on the basis of benthic foraminifers, in the successions studied (Table 1). Besides the occurrences at Sites 878 and 879 , Assemblage I of late Albian age is also present at the tops of the Resolution and Allison guyots (Leg 143) as well as in dredge hauls from the edges of MIT Guyot (Grötsch et al., 1993). A small foraminifer fauna similar to Assemblage 0 of latest Albian age, identified at the top of the platform sequence at Takuyo-Daisan, was recorded from dredges on the top of DaiichiKashima (Shiba, 1988). Furthermore, Konishi (1989) mentioned a few calcareous algae from the same dredges at Daiichi-Kashima, similar to those described from Site 879 by Masse and Arnaud Vanneau (this volume), but most of the species identified by the latter authors are reported for the first time from the Pacific region. Rare cuneolinids and orbitolinids, not specifically identified, were also recorded at Site 315 (Line Islands), Site 171 and Isakov Guyot (MidPacific Mountains), and Site 585 (East Marianna Basin) (Schlanger 
Table 1. Aptian-Albian benthic foraminifer assemblages recorded at Sites 878 (MIT Guyot) and 879 (Takuyo-Daisan Guyot) (after Arnaud Vanneau and Premoli Silva, this volume).

\begin{tabular}{|c|c|}
\hline Assemblage 0 & $\begin{array}{l}\text { Nezzazata isabellae } \\
\text { Cuneolina stiteri } \\
\text { Cuneolina parva } \\
\text { Cuneolina cf. pavonia } \\
\text { Fischerina? carinata } \\
\text { Trocholina altispira } \\
\text { Paracoskinolina cf. sunnilandensis } \\
\text { Orbitolina } \text { sp. } \\
\text { Orbitolina (Conicorbitolina) cf. aliensis }\end{array}$ \\
\hline Assemblage I & $\begin{array}{l}\text { Nezzazata isabellae } \\
\text { Cuneolina sliteri } \\
\text { Cuneolina parva } \\
\text { Cuneolina cf. pavonia } \\
\text { Pseudonummoloculina sp. }\end{array}$ \\
\hline Assemblage II & $\begin{array}{l}\text { Nezzazata isabellae } \\
\text { Cuneolina sliteri } \\
\text { Cuneolina parva } \\
\text { Pseudonummoloculina aurigerica } \\
\text { Arenobulimina cf. chapmani }\end{array}$ \\
\hline Assemblage III & $\begin{array}{l}\text { Nezzazata isabellae } \\
\text { Cuneolina sliteri } \\
\text { Orbitolina (Mesorbitolina) texana oculata } \\
\text { Voloshinoides? sp. C } \\
\text { Coskinolinella navarrensis }\end{array}$ \\
\hline Assemblage IV & $\begin{array}{l}\text { Cuneolina sliteri } \\
\text { Orbitolina (Mesorbitolina) ef. pervia } \\
\text { Voloshinoides? sp. C } \\
\text { Coskinolinella daguini }\end{array}$ \\
\hline Assemblage $\mathrm{V}$ & $\begin{array}{l}\text { Vercorsella cf. immaturata } \\
\text { Nezzazata? sp. C } \\
\text { Valvulineria? n. sp. } 1 \\
\text { Voloshinoides? sp. D } \\
\text { Arenobulimina sp. A } \\
\text { Ammobaculites celatus }\end{array}$ \\
\hline Assemblage VI & $\begin{array}{l}\text { Nezzazata? sp. C } \\
\text { Valvulineria? n. sp. I } \\
\text { Neotrocholina cf. infragramulata }\end{array}$ \\
\hline
\end{tabular}

and Premoli Silva, 1981; Moberly, Schlanger, et al., 1986). These records indicate that a similar shallow-water foraminifer assemblage was widespread in the Pacific, at least in the late Albian.

\section{Faunal and Floral Biogeographic Affinities}

The foraminifer assemblages identified at Sites 878 and 879 include a mixture of species well known along the Arabo-African Tethyan margin, such as Praechrysalidina sp. cf. P. infracretacea and Trocholina altispira, as well as Pseudonummoloculina aurigerica, Coskinolinella navarrensis, Coskinolinella daguini, and Fischerina? carinata from the European margin (Arnaud Vanneau and Sliter, 1994). There are also species first described from the American region such as Orbitolina (Mesorbitolina) texana oculata, Paracoskinolina sp. cf. P. sunnilandensis, and probably Orbitolina (Mesorbitolina) sp. cf. $O$. (M.) pervia, but these species have a worldwide distribution (i.e., they are cosmopolitan; Arnaud Vanneau and Premoli Silva, this volume) (Table 2).

Among the calcareous algae, Parachetetes asvapatii, Polystrata alba, Neomeris cretacea, and Similiclypeina somalica represent the Tethyan cosmopolitan elements (Masse and Arnaud Vanneau, this volume) (Table 2 ). In the early Aptian, the algal assemblages from Sites 878 and 879 include the taxa Acroporella radoiciciae, Montiella elitzae, Salpingoporella sp. cf. S. muehlbergii, and S. cf. melitae, which are typical forms from the Mediterranean area and are not documented from the Caribbean region (Granier et al., 1991). On the other hand, in the Albian the algal floras include the taxa Triploporella sp. aff. T. steinmannii and Cylindroporella sp. cf. C. barnesii, which exhibit a Caribbean affinity.

A cosmopolitan Tethyan character is also displayed by the few corals identified at the generic level (see A.F. Budd, in Appendix), whereas Swinburne and Masse (1995) reported that the rudists from
Mid-Pacific Mountains (Leg 143 sites) exhibited some endemism in the late Albian.

\section{Late Campanian-Maastrichtian}

Upper Campanian-Maastrichtian shallow-water sediments were recovered at five sites drilled on the summit of Wodejebato Guyot. These sites were located in the center of the guyot (Site 873), on the northeastern inner perimeter (Sites 874 and 877) and on the outer perimeter (Sites 875 and 876 ) ridges. The thickness of the platform sediments varies from $82.2 \mathrm{~m}$ at the lagoonal setting (Site 873 ) to a maximum of about $183 \mathrm{~m}$ at the thickest bioconstructed location of Site 877. Intermediate thicknesses were measured at the other three sites: the thickness of the platform is about $163 \mathrm{~m}$ at the second bioconstructed Site 874 , whereas the shallow-water sediments were $126 \mathrm{~m}$ and $145 \mathrm{~m}$ thick, respectively, at the two most external sites (875 and 876).

At the bottom of the lagoonal and inner ridge sites, large benthic foraminifer assemblages are dominated by Pseudorbitoides trechmanni associated with rare Vaughanina, Asterorbis, and Sulcoperculina. Higher in the succession, benthic foraminiferal faunas consist of common to abundant Sulcoperculina and Asterorbis, associated with Omphalocyclus macroporus at the top of the platform. In the middle part of the sequence at Site 877 , rare Orbitoides sp. (close to $O$. media) were found that represent a minor, but significant element of the fauna. The same taxon was also recovered from a dredge sample from the southern slope of the guyot (Lincoln et al., 1993). Several specimens of Vidalina hispanica, rare Pseudocyclammina sp., and Montsechiana $\mathrm{sp}$. within the succession point to a more restricted facies. These species occur at all three sites, although with different vertical distributions. Dicyclina sp. cf. D. schlumbergeri and Idalina antiqua, on the contrary, were recorded only at Site 873. Among the calcareous algae, encrusting corallinaceans and Polystrata alba are dominant at all three sites; some layers, however, yielded erect corallinaceans and, at the lagoonal Site 873 , a few dasycladaceans, $C y$ mopolia, and Salpingoporella (Premoli Silva et al., this volume).

At the inner ridge Sites 874 and 877 , two lithologic subunits contained several rudists belonging to the radiolitids (Distefanella mooretownensis, Distefanella sp.), plagioptychids (Mitrocaprina sp., Coralliochama orcutti, Coralliochama sp., Plagioptychus aff. fragilis, $P$. aff. minor), and antillocaprinids (Antillocaprina sp.) (see Appendix; see also Camoin et al., this volume). A few corals were also recorded, but their poor preservation prevented identification.

At the outer ridge sites ( 875 and 876 ), the pseudorbitoidids are present only as reworked elements within an assemblage dominated by sulcoperculinids and Asterorbis, associated in the lower half of the sequence, at least at Site 875, with common Omphalocyclus macroporus. Asterorbis is consistently present and abundant up to the top of the platform deposits, whereas sulcoperculinids are absent in the uppermost $25 \mathrm{~m}$ of the carbonate platform at Site 875 and in the upper $90 \mathrm{~m}$ at Site 876. Rare possible Lepidorbitoides were also found in the middle part of the Site 875 sequence. Accompanying calcareous algae, corallinaceans and Polystrata alba, are abundant but frequently fragmented. Rudists are common components of the bioclasts, but they are present only as fragments, whereas corals are rare.

Some elements of these assemblages (e.g., rudists, sulcoperculinids, Asterorbis, and a few Orbitoides sp.) were identified in the dredge haul from the southern slope of Wodejebato (Lincoln et al., 1993). Moreover, several specimens of Pseudorbitoides trechmanni along with a possible Vaughanina were recovered in the volcaniclastic sediments at the apron Site 869 drilled in the abyssal plain south of Wodejebato (Sager, Winterer, Firth, et al., 1993; Erba et al., this volume).

A larger assemblage comprising most of the benthic foraminifer taxa mentioned above was described from Site 462, which was drilled in the Nauru Basin. There, shallow-water debris is present, sometimes in abundance, at different stratigraphic levels as allochthonous ele- 
Table 2. Aptian-Albian benthic foraminifers and calcareous algae from Sites 878 (MIT Guyot) and 879 (Takuyo-Daisan Guyot), arranged according to bioprovincial affinities (after Arnaud Vanneau and Premoli Silva, and Masse and Arnaud Vanneau, both this volume).

\begin{tabular}{|c|c|c|c|}
\hline Ages & Cosmopolitan taxa & Mediterranean taxa & Caribbean taxa \\
\hline late Albian & $\begin{array}{l}\text { Cuneolina parva } \\
\text { Cuneolina cf. pavonia } \\
\text { Paracoskinolina cf. sunnilandensis } \\
\text { Polystrata alba } \\
\text { Similiclypeina somalica }\end{array}$ & $\begin{array}{l}\text { Fischerina? carinata } \\
\text { Trocholina altispira } \\
\text { Triploporella } \text { aff. steinmannii }\end{array}$ & $\begin{array}{l}\text { Parachetetes aswapatii } \\
\text { Neomeris cretacea } \\
\text { Cylindroporella } \mathrm{cf} \text {, barnesii }\end{array}$ \\
\hline Aptian-Albian & $\begin{array}{l}\text { Orbitolina (Mesorbitolina) texana oculata } \\
\text { Orbitolina (Mesorbitolina) cf. pervia }\end{array}$ & $\begin{array}{l}\text { Praechrysalidina cf. infracretacea } \\
\text { Pseudonummoloculina aurigerica } \\
\text { Coskinolinella navarrensis } \\
\text { Coskinolinella daguini }\end{array}$ & \\
\hline early Aptian & & $\begin{array}{l}\text { Salpingoporella } \text { cf. muehlbergii } \\
\text { Salpingoporella } \text { cf. melitae } \\
\text { Acroporella radoiciciae } \\
\text { Montiella elitzae }\end{array}$ & \\
\hline
\end{tabular}

ments of the coarser layers within deep-sea host deposits (Premoli Silva and Brusa, 1981). The same benthic foraminifers were also recovered in an analogous setting along the Line Islands chain at Sites 165, 315, and 316 (Beckmann, 1976; Premoli Silva and Brusa, 1981).

The only species never found at any other deep-sea site except Wodejebato are Omphalocyclus macroporus and Orbitoides sp. However, representatives of the genus Orbitoides and Omphalocyclus macroporus together with Pseudorbitoides were recorded from Papua (Glaessner, 1960). Moreover, these taxa along with Lepidorbitoides and a possible Asterorbis (Sulcorbitoides in Hashimoto et al., 1978) were described by Hashimoto et al. (1978) from a sandstone conglomerate cropping out in central Luzon (Philippines).

\section{Faunal and Floral Biogeographic Affinities}

The main components of the late Campanian-Maastrichtian faunal assemblages recovered from Wodejebato Guyot and other currently western Pacific sites and locations are elements typical of the Caribbean-central American bioprovince (Table 3). In fact, Pseudorbitoides, Vaughanina, Asterorbis, and Sulcoperculina, conspicuous faunal elements of this bioprovince, are unknown in the Mediterranean realm (see Dilley, 1971, 1973; Van Gorsel, 1978; Krijnen et al., 1993). The great affinity of the Late Cretaceous larger benthic foraminifer assemblages of the central Pacific with those of the Caribbean-central American bioprovince was already pointed out by Beckmann (1976) and further supported by the findings at Site 462 in the Nauru Basin (Premoli Silva and Brusa, 1981).

In addition to these Caribbean elements, Beckmann (1976) and Premoli Silva and Brusa (1981) also identified some representatives of the Lepidorbitoides evolutionary lineage, which according to Van Gorsel (1978), should be restricted to the "Eurasian" bioprovince. The identification of Lepidorbitoides, however, was later rejected by Butterlin (1992), who stated that these forms were attributable to the genus Orbitocyclina, yet another element of the Caribbean fauna. The validity of the Orbitocyclina and the relationship between this genus and Lepidorbitoides is presently debated and under study (E. Caus, pers. comm., 1994). Questionable Lepidorbitoides may also be present at Site 875 on Wodejebato Guyot.

The foraminifer fauna at Wodejebato also yielded numerous $\mathrm{Om}$ phalocyclus macroporus and rare Orbitoides sp. (close to O. media). According to Van Gorsel (1978), these species (lacking in the Nauru Basin material) are cosmopolitan, as they are recorded from both Tethyan and Caribbean bioprovinces. Their stratigraphic range, however, appears more restricted at Wodejebato than the total range known from other localities, especially European ones. This is particularly evident for the Orbitoides lineage, which is represented here only by a single evolutionary species. The association of genera from Wodejebato is similar, although richer in specimens and species, to those observed in Papua (Glaessner, 1960) and in Luzon (Hashimoto et al., 1978).

According to Camoin et al. (this volume; see also Appendix, this chapter), the rudists identified at Wodejebato are also characteristic of the Caribbean region and have not yet been recorded from the Mediterranean area. However, other "Caribbean-type" rudists have been documented from the eastern Old World Tethyan sites, as recorded by Skelton and Wright (1987) and Skelton (1988) (Fig. 1).

\section{Latest Paleocene-Early Middle Eocene}

Almost $290 \mathrm{~m}$ of shallow-water carbonate deposits were recovered at Site 871 (Limalok Guyot). These are mainly of early to early middle Eocene age, with the lowermost layers belonging to the latest Paleocene. Larger benthic foraminifers are the most important fossil group. Calcareous algal assemblages are dominated by either encrusting or branched corallinaceans, associated with common Polystrata alba especially in the colonizing community. Other identified algae are rare Cymopolia, Salpingoporella, Halimeda, and Thaumatoporella. Rare corals and bivalves were also recorded (see Nicora et al., this volume).

Remarkable among the larger benthic foraminifers is the presence of abundant Alveolina, which include Alveolina (Glomoalveolina) sp., A. (Alveolina) ilerdensis, A. (A.) pinguis, and flosculine alveolinids. Other larger foraminifers identified include (1) common Asterocyclina (no species identified), (2) some Discocyclina, with D. barkeri found at the base of the sequence, (3) Nummulites, with few species identified at specific level (i.e., Nummulites sp. aff. $N$. deserti from the lower middle half, $N$. nitidus group in the middle upper part, and $N$. laevigatus in the upper part of the succession), and (4) Coleiconus elongatus in the upper part of the sequence.

Other components of the faunas are abundant small and large miliolids throughout the entire sequence, and a few Praerhapydionina and Pseudochrysalidina in the upper part of the platform sequence. A small fauna with nummulitids and discocyclinids was also recovered from dredge hauls at the edge of Limalok (Schlanger et al., 1987).

A large assemblage with common Nummulites, discocyclinids, asterocyclinids, and a single specimen of a poorly preserved Alveolina of early Eocene age was recovered from Site 462 drilled in the Nauru Basin (Premoli Silva and Brusa, 1981). As for the Cretaceous assemblage, these shallow-water forms are present at different stratigraphic levels as allochthonous elements of the coarser layers within deep-sea host deposits. Identified species are Nummulites pernotus and Assilina leymeriei of earliest Eocene age, and Nummulites burdigalensis, $N$. partschi, and $N$. rotularius of middle to late early Eocene age. These species were not encountered in the cores from Limalok Guyot, and in our opinion, their absence is probably related to the restricted environment characterizing the lagoonal setting at that time, which was unsuitable for nummulitids.

In addition, Hashimoto et al. (1978) identified Assilina sp. and Ranikothalia bermudezi from the same sandstone conglomerate cropping out in central Luzon (Philippines), which yielded the Late Cretaceous benthic foraminifers described above. Again, these forms are missing at Limalok. Eocene shallow-water organisms, comparable with those recovered at Limalok Guyot, occur as far east as the Line Islands and Tuamotu (see Premoli Silva and Brusa, 1981). How- 
Table 3. Late Campanian to early middle Eocene rudists, benthic foraminifers, and calcareous algae from Sites 871 (Limalok Guyot) and 873-877 (Wodejebato Guyot), arranged according to bioprovincial affinities (after Nicora et al., Premoli Silva et al., and Camoin et al., all this volume).

\begin{tabular}{|c|c|c|c|}
\hline Ages & Cosmopolitan taxa & Mediterranean taxa & Caribbean taxa \\
\hline middle Eocene & Discocyclinids & Nummulites laevigatus & Coleiconus elongatus \\
\hline early Eocene & $\begin{array}{l}\text { Asterocyclinids } \\
\text { Praerhapydionina } \\
\text { Pseudochrysalidina } \\
\text { Asterocyclinids } \\
\text { Polystrata alba }\end{array}$ & $\begin{array}{l}\text { Nummulites nitidus gr. } \\
\text { Alveolina pinguis } \\
\text { Alveolina ilerdensis } \\
\text { Nummulites aff. deserti } \\
\text { Flosculine alveolinids }\end{array}$ & \\
\hline latest Paleocene & $\begin{array}{l}\text { Discocyclinids? } \\
\text { Polystrata aiba }\end{array}$ & Alveolinids & Discocyclina barkeri \\
\hline $\begin{array}{l}\text { Maastrichtian } \\
\text { and } \\
\text { late Campanian }\end{array}$ & $\begin{array}{l}\text { Orbitoides sp. } \\
\text { Omphalocyclus } \\
\text { Polystrata alba }\end{array}$ & $\begin{array}{l}\text { Idalina antiqua } \\
\text { Vidalina hispanica } \\
\text { Montsechiana sp. } \\
\text { Dicyclina cf. schlumbergeri } \\
\text { Pseudocyclammina sp. } \\
\text { Salpingoporella sp. } \\
\text { Coralliochama orcutti }\end{array}$ & $\begin{array}{l}\text { Sulcoperculina spp. } \\
\text { Asterorbis roocki } \\
\text { Vaughanina } \mathrm{sp} \text {. } \\
\text { Pseudorbitoides trechmanni } \\
\text { Distefanella mooretownensis } \\
\text { Mitrocaprina sp. } \\
\text { Coralliochama sp. } \\
\text { Plagioptychus aff. fragilis } \\
\text { Plagioptychus aff. minor } \\
\text { Antillocaprina sp. }\end{array}$ \\
\hline
\end{tabular}

ever, the foraminifer assemblages in these areas are predominantly composed of discocyclinids and asterocyclinids, whereas nummulitids and alveolinids are missing. Only from later in the Eocene a single species of Nummulites (close to $N$. variolarius) was recorded by Beckmann (1976) from Tuamotu (Site 318).

\section{Faunal and Floral Biogeographic Affinities}

The principal components of the benthic foraminifer faunas recovered from lower and lower middle Eocene shallow-water sediments at Limalok Guyot are alveolinids, nummulitids, asterocyclinids, and discocyclinids (Table 3 ). The first two fossil groups are known to typify Tethyan assemblages in the Eocene, and their areal distribution, at least at the generic level, extended toward the east as far as the Indo-Pacific margin (Adams, 1973; Hottinger, 1971, 1973). Several species of Nummulites and especially Alveolina, identified at Limalok or in the Nauru Basin, were described from the Mediterranean area (Hottinger, 1960; Schaub, 1981). At first sight, the Alveolina-bearing layers recovered at Limalok (Premoli Silva, Haggerty, Rack, et al., 1993, p. 56, fig. 13) exhibit a remarkable similarity with some horizons cropping out at Tremp (Spain), the stratotype of the Ilerdian stage (see Hottinger, 1960). The other groups, asterocyclinids and discocyclinids, include numerous Asterocyclina and less common Discocyclina. These two genera are cosmopolitan but exhibit some provinciality at the specific level. Although both genera are presently under revision, we could confidently identify Discocyclina barkeri at the base of the platform sequence in association with poorly preserved alveolinids. This species was described from the Caribbean (Ellis and Messina, 1967). A second Caribbean species, Coleiconus elongatus, was observed in the upper part of the Limalok platform sequence associated with Nummulites laevigatus.

\section{DISCUSSION}

Taking into consideration the overall poor recovery obtained by drilling shallow-water carbonate sequences at Limalok, Wodejebato, MIT, and Takuyo-Daisan guyots during Leg 144, the faunas and floras of these guyots are rather rich in species as well as individuals in all the stratigraphic intervals. However, the species richness recorded from these guyots, even if supplemented with the record from redeposited material of nearby locations, cannot compare with the species diversity observed in coeval carbonate platforms cropping out on land, where lateral as well as vertical distributions could be studied in detail. Even at Wodejebato, the five sites, drilled ad hoc, represent a discrete sampling of a few centimeters compared with tens to hundreds of meters in the land-based sequences. Because of this overall poor sampling, the faunal and floral associations collected acquired great importance, allowing us to tentatively reconstruct the bioprovincial evolution.

Figure 1 outlines the areal distribution at a global scale of the faunal and floral assemblages in early Aptian, late Albian, late Campanian-Maastrichtian, and early-middle Eocene age intervals of platform growth on the Pacific guyots. According to the paleolatitudes reconstructed during Leg 144 (see Larson et al., this volume), the guyots studied were all located in the Southern Hemisphere around $10^{\circ} \mathrm{S}$ at the time of the inception of carbonate deposition.

As previously described, the Aptian and most Albian assemblages are largely composed of taxa diffused along both margins of the Tethyan Ocean, which extended from Central America as far east as eastern Asia at that time (Camoin et al., 1993; Masse et al., 1992a, 1992b, 1993a, 1993b). The fossil record from the guyots drilled during Leg 144 indicates that the Tethyan bioprovince may have extended eastward to include the central Pacific area. Apparently, no endemic species were present at that time. From the late Aptian onward, a discrete bioprovince started to differentiate in the Caribbean-central American region from the main Tethyan early Aptian bioprovince (see e.g., Skelton, 1988; Masse et al., 1993b). In the late Albian, the shallow-water assemblages here studied predominantly consist of cosmopolitan species or with Tethyan affinity, but they also comprise some dasycladacean algae recorded only from the Caribbean-central American region. This finding is consistent with the rudist record from the Mid-Pacific Mountains (Leg 143), which indicates that some endemism was acquired by this group in late Albian time (see Swinburne and Masse, 1995). This suggests that the Pacific guyots were located on an area of overlap of the two bioprovinces, the old Tethyan and the new differentiating Caribbean one.

By Campanian-Maastrichtian time, the Tethyan and Caribbean bioprovinces were well established at low latitudes, possibly further divided into a few subprovinces (e.g., Dilley, 1971, 1973; Van Gorsel, 1978). A Tethyan assemblage outlined the Tethyan bioprovince that extended from the Atlantic European margin (on the west) to southeast Asia (on the east). The Caribbean bioprovince was located in the Caribbean-central American area. Cosmopolitan species (i.e., species common to both bioprovinces) were represented by Orbitoides and Omphalocyclus (Van Gorsel, 1978).

The central Pacific benthic foraminifer assemblage was strongly dominated by Caribbean taxa such as pseudorbitoidids, Asterorbis, and sulcoperculinids. These occur in association with rudists, known exclusively from the Caribbean, and with a few cosmopolitan Orbitoides and Omphalocyclus, which apparently exhibit a more stratigraphically limited distribution. However, some Mediterranean elements such as Dicyclina, Vidalina hispanica, and Idalina antiqua (see Loeblich and Tappan, 1988), were also recorded in the lagoonal facies 
early Aptian

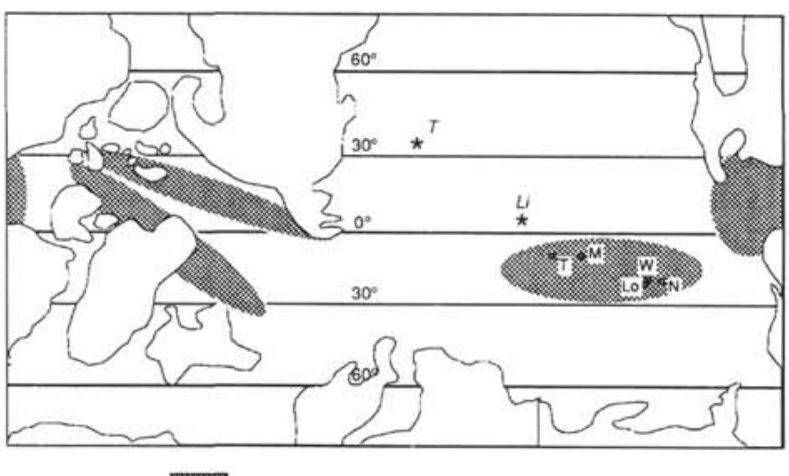

Cosmopolitan Tethyan assemblage

Campanian-Maastrichtian

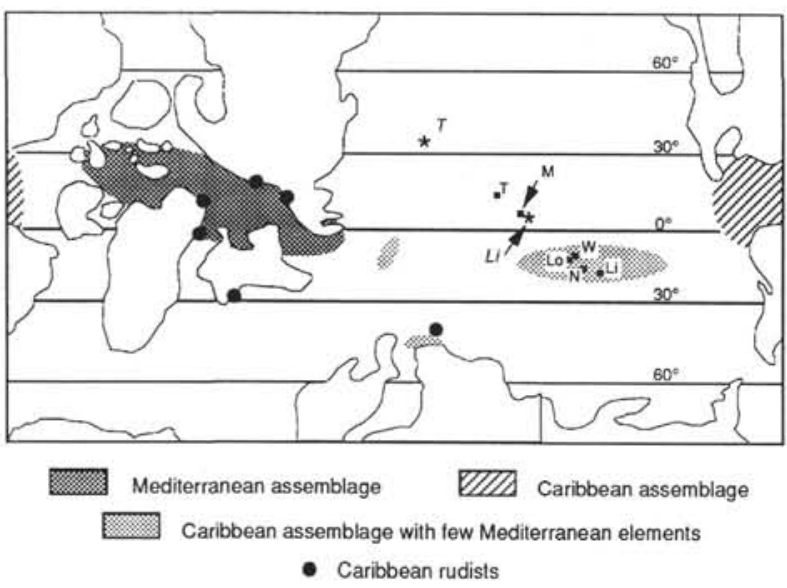

late Albian

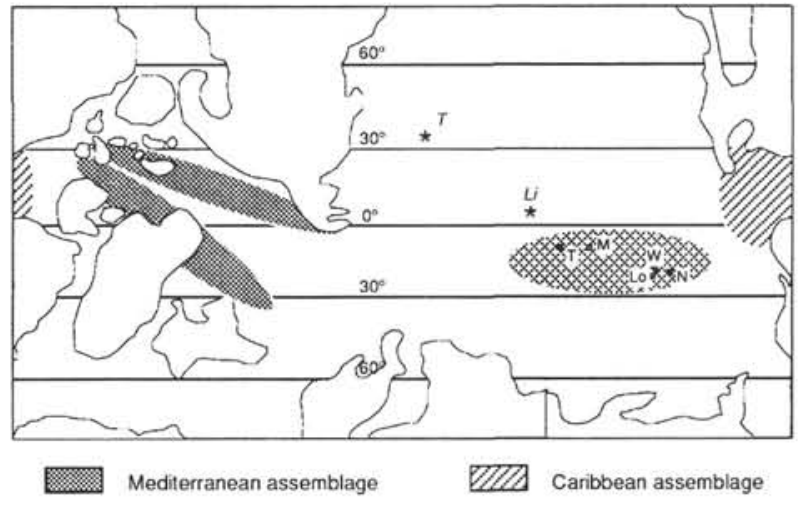

Mediterranean assemblage with lew Caribbean elements

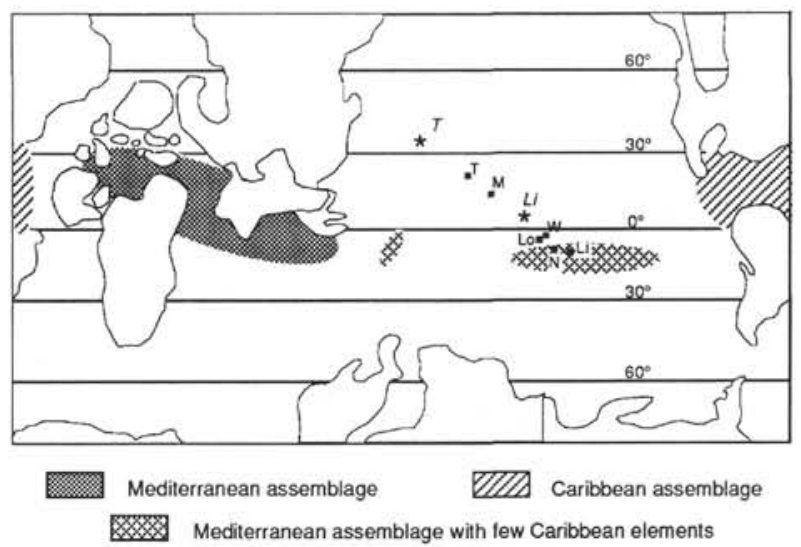

Figure 1. Tentative distribution of paleobioprovinces in early Aptian, late Albian, late Campanian-Maastrichtian, and early Eocene time with the location of the guyots drilled during Leg 144. Guyots (squares) are plotted according to the reconstructed paleolatitudes of Larson et al. (this volume). Black dots = record of Caribbean rudists after Skelton (1988). Asterisks mark the present location of the northernmost and southernmost guyots of the transect. $\mathrm{Li}=\mathrm{Limalok} ; \mathrm{Lo}=\mathrm{Lo}-\mathrm{En}$; $\mathrm{M}=$ MIT; $\mathrm{N}=$ Nauru Basin, Site 462; $\mathrm{T}=$ Takuyo-Daisan; and W = Wodejebato. Maps modified from Roth (1981).

at Wodejebato, and possible Lepidorbitoides were found at Site 875. The presence of Mediterranean elements within a predominantly Caribbean assemblage suggests that either these elements are essentially cosmopolitan and so far were never recognized from the Caribbean region or the Pacific guyots were located on the crossroad between the two bioprovinces. The first hypothesis would argue for the Caribbean bioprovince to have been extended to the west to include the central Pacific region, whereas the second hypothesis favors the identification of a new bioprovince or subprovince characterized by elements from both Mediterranean and Caribbean bioprovinces.

It is worth mentioning that some rudist taxa with Caribbean-central American affinities (i.e., Torreites and Thyrastylon) have been recorded as far west as Iran and Oman around the eastern Tethyan ocean (Skelton and Wright, 1987; Skelton, 1988) (see Fig. 1).

In early and early middle Eocene time, the guyots' assemblages were dominated by Tethyan elements such as alveolinids and nummulitids, which are missing in the Caribbean. The very few Nummulites recorded in the latter region belong to different species. Asterocyclinids and discocyclinids in the Eocene assemblage may be representatives of the cosmopolitan group, but their evolution is still so poorly known that further interpretations are totally premature. It is certain, however, that Discocyclina barkeri and Coleiconus elongatus of the Caribbean bioprovince occur in association with the Tethyan fauna. During the early-middle Eocene, we are confronted with a situation similar to that of Campanian-Maastrichtian period, except that it is the Tethyan bioprovince which may have been extended eastward to include the central Pacific. Yet again, the identification of a central Pacific subprovince cannot be ruled out.

\section{CONCLUSIONS}

Shallow-water organisms recovered by drilling the guyots in the western Pacific provide information on the distribution of larger foraminifers, rudists, corals, and calcareous algae, and have greatly increased our knowledge about the Cretaceous and Early Tertiary bioprovinces. The oldest records, of early Aptian age, confirm the cosmopolitan Tethyan character of the low-latitude foraminifer and rudist assemblages associated with carbonate platforms. Contrary to expectation, also calcareous algae and especially dasycladaceans show a much wider geographical distribution.

By late Albian time, the high level of endemism characterizing the Caribbean bioprovince, probably related to the wider Atlantic acting as a significant barrier to dispersal of most sensitive shallow-water organisms (see discussion in Skelton, 1988), also started to affect the guyots' region as supported by the record of dasycladaceans of Caribbean affinity and endemic rudists from the drill holes. This means that a dispersal route in a westward direction was activated from the Caribbean as far as the central Pacific region by that time (Fig. 1).

During the late Campanian-Maastrichtian, shallow-water organisms (foraminifers and rudists) of the central Pacific display great 
affinities with the Caribbean-central American bioprovince, although associated with some Mediterranean elements. Based on the presence of Lepidorbitoides, now questioned, Premoli Silva and Brusa (1981) suggested that a new bioprovince was distinguishable in the central Pacific, characterized by the association of Caribbean and Mediterranean elements.The occurrence of elements from both bioprovinces may be explained by assuming that the direction of migration toward the guyots' region was predominantly from the west, although a minor migration from the east might have existed. It is well known that shallow-water faunas and floras cannot easily migrate across a large, deep ocean, such as the present eastern Pacific, which would act as a barrier.

Schlanger et al. (1981), based on a still preliminary plate reconstruction, suggested that at first the Caribbean Plate was probably located much more to the west than its present position, which would place it closer to the guyots' region; and, second, a number of shallow "stepping stones" existed between the Caribbean area and the guyots studied. Because the intraplate volcanism that created Wodejebato Guyot was a widespread phenomenon of the Pacific Plate, edifices rising from the seafloor to reach the photic zone were probably numerous in the Late Cretaceous (see Lincoln et al., 1993). This interpretation was followed and further supported by Skelton and Wright (1987) and Skelton (1988) for explaining the disjunct distribution of Maastrichtian rudists in the Caribbean and eastern Tethys (Iran, Oman). Camoin et al. (1993) reemphasize the function of the general oceanic surface circulation in the dispersal of shallow-water organisms. The main Pacific equatorial current system flowing from east to west could have easily dispersed the shallow-water organisms, originated in the Caribbean region, across the central Pacific towards the eastern Tethys. On the other hand, the recent numerical ocean circulation model (Barron and Peterson, 1989) shows that a clockwise gyretype circulation existed between Eurasia and Africa, which probably produced a flow toward the east facilitating the eastward dispersal of the Tethyan elements toward the central Pacific. This eastward migration could have occurred because some "stepping stones" (i.e., island arcs, small continental blocks, etc.) were probably available at that time between India and Eurasia and in the western Pacific.

During the Early Tertiary, the direction of the main faunal migration, and thus of colonization, was reversed with respect to Late Cretaceous time, from west to east, the latter dispersal direction prevailing at the present time. This shift can be explained by the growth, since Late Cretaceous time, of the large, deep eastern Pacific Basin, which led initially to an increasingly difficult migration and eventual cessation of colonization from the east. On the other hand, this shift coincides with a time of major tectonic reorganization in the southeastern Asian region, with the possible formation of new "stepping stones" on the western side of the Pacific favoring colonization from the Mediterranean toward the central Pacific.

\section{ACKNOWLEDGMENTS}

P.W. Skelton and J.P. Krijnen are warmly thanked for suggestions and review of the manuscript. The research was supported by Italian CNR funds to IPS.

\section{REFERENCES}

Adams, C.G., 1973. Some Tertiary foraminifera. In Hallam, A. (Ed.), Atlas of Palaeobiogeography: Amsterdam (Elsevier), 453-471.

Arnaud Vanneau, A., and Sliter, W.V., 1994. Lower Cretaceous benthic foraminifers from carbonate platforms of Pacific guyots and their relationship to Tethyan species. PaleoBios, 16(suppl.):22.

\footnotetext{
-Abbreviations for names of organizations and publications in ODP reference lists follow the style given in Chemical Abstracts Service Source Index (published by American Chemical Society).
}

1995. Early Cretaceous shallow-water benthic foraminifers and fecal pellets from Leg 143 compared with coeval faunas from the Pacific Basin, Central America, and the Tethys. In Winterer, E.L., Sager, W.W., Firth, J.V., and Sinton, J.M. (Eds.), Proc. ODP, Sci. Results, 143: College Station, TX (Ocean Drilling Program), 537-564.

Barron, E.J., and Peterson, W.H., 1989. Model simulation of the Cretaceous Ocean circulation. Science, 244:684-686.

Beckmann, J.P., 1976. Shallow water foraminifers and associated microfossils from Sites 315, 316 and 318, DSDP Leg 33. In Schlanger, S.O., Jackson, E.D., et al., Init. Repts. DSDP, 33: Washington (U.S. Govt. Printing Office), 467-470.

Butterlin, J., 1992. Données nouvelles sur la distribution géographique d'espèces américaines de grands foraminifères du Crétacé terminal. Geobios, Mem. Spec., 14:29-34.

Camoin, G., Bellion, Y.J.C., Dercourt, J., Guiraud, R., Lucas, J., Poisson, A., Ricou, L.E., and Vrielynck, B., 1993. Late Maastrichtian (69.5-65 Ma). Explanatory notes. In Dercourt, J., Ricou, L.E., and Vrielynck, B. (Eds.), Atlas Tethys Paleoenvironmental Maps: Paris (Gauthier Villars), 179-196.

Dilley, F.C., 1971. Cretaceous foraminiferal biogeography. In Middlemiss, F.A., Rawson, P.F., and Newall, G. (Eds.), Faunal Provinces in Space and Time. Geol. J., 4:169-190.

, 1973. Cretaceous larger Foraminifera. In Hallam, A. (Ed.), Atlas of Palaeobiogeography: Amsterdam (Elsevier), 403-419.

Ellis, B.F., and Messina, A.R., 1967. Catalogue of Index Foraminifera: New York (American Museum of Natural History).

Glaessner, M.F., 1960. Upper Cretaceous larger foraminifera from New Guinea. Sci. Rep. Tohoku Univ., Ser. 2 (Geol.) Spec., 4:37.

Granier, B., Berthou, P.Y., and Fourcade, E., 1991. The Dasycladacean algae from the Cretaceous of the New World. Trans. 2nd Geol. Conf., Geol. Soc., Trinidad and Tobago, 178-183.

Grötsch, J., Schroeder, R., Noé, S., and Flügel, F., 1993. Carbonate platforms as recorders of high-amplitude eustatic sea-level fluctuations: the late Albian appenninica event. Basin Res., 5:197-212.

Hashimoto, W., Matsumaru, K., and Kurihara, K., 1978. Larger Foraminifera from the Philippines. VI. Larger Foraminifera found from the Pinugay Hill Limestone, Tanay, Rizal, Central Luzon. In Kobayashi, T., Toriyama, R., and Hashimoto, W. (Eds.), Geol. Palaeontol. Southeast Asia, 19:65-72.

Hottinger, L., 1960. Recherches sur les Alvéolines du Paléocène et de l' Eocène. Mem. Suisses Paléontol., 75-76.

, 1971. Larger foraminifera common to Mediterranean and Indian Paleocene and Eocene formations. Ann. Hung. Geol. Inst., 54:143-151.

, 1973. Selected Paleogene larger foraminifera. In Hallam, A. (Ed.), Atlas of Palaeobiogeography: Amsterdam (Elsevier), 443-452.

Konishi, K., 1989. Limestone of the Daiichi Kashima Seamount and the fate of a subducting guyot: fact and speculation from the Kaiko "Nautile" dives. Tectonophysics, 160:249-265.

Krijnen, J.P., MacGillavry, H.J., and Van Dommelen, H., 1993. Review of upper Cretaceous orbitoidal larger foraminifera from Jamaica, West Indies, and their connection with rudist assemblages. Mem.-Geol. Soc. Am., 182:29-63.

Lincoln, J.M., Pringle, M.S., and Premoli-Silva, I., 1993. Early and Late Cretaceous volcanism and reef-building in the Marshall Islands. In Pringle, M.S., Sager, W.W., Sliter, W.V., and Stein, S. (Eds.), The Mesozoic Pacific: Geology, Tectonics, and Volcanism. Geophys. Monogr., Am. Geophys. Union, 77:279-305.

Loeblich, A.R., Jr., and Tappan, H., 1988. Foraminiferal Genera and Their Classification: New York (Van Nostrand Reinhold).

Masse, J.-P., 1992a. The Lower Cretaceous Mesogean benthic ecosystems: palaeoecologic aspects and palaeobiogeographic implications. Palaeogeogr., Palaeoclimatol., Palaeoecol., 91:331-345.

1992b. The Lower Cretaceous Mesogée: a state of the art. In New Aspects of Tethyan Cretaceous Fossil Assemblages. Schrift. Erdwiss. Komm., Oester. Akad. Wiss., 9:15-34.

Masse, J.-P., Bellion, Y., Benkelil, J., Boulin, J., Cornee, J.J., Dercourt, J., Guiraud, R., Mascle, G., Poisson, A., Ricou, L.E., and Sandulescu, M., 1993a. Lower Aptian 114-112 Ma. Maps. In Dercourt, J., Ricou, L.E., and Vrielinck, B. (Eds.), Atlas Tethys, Palaeoenvironmental Maps: Rueil-Malmaison (BEICIP-FRANLAB).

Masse, J.-P., Bellion, Y., Benkelil, J., Ricou, L.E., Dercourt, J., and Guiraud, R., 1993b. Lower Aptian (114 to 111 Ma). Explanatory notes. In Dercourt, J., Ricou, L.E., and Vrielinck, B. (Eds.), Atlas Tethys Paleoenvironmental Maps: Paris (Gauthier Villars), 135-143.

Moberly, R., Schlanger, S.O., et al., 1986. Init. Repts. DSDP, 89: Washington (U.S. Govt. Printing Office). 
Premoli Silva, I., and Brusa, C., 1981. Shallow-water skeletal debris and larger foraminifers from Deep Sea Drilling Project Site 462, Nauru Basin, western equatorial Pacific. In Larson, R.L., Schlanger, S.O., et al., Init. Repts. DSDP, 61: Washington (U.S. Govt. Printing Office), 439-473.

Premoli Silva, I., Haggerty, J., Rack, F., et al., 1993. Proc. ODP, Init. Repts., 144: College Station, TX (Ocean Drilling Program).

Roth, P.H., 1981. Mid-Cretaceous calcareous nannoplankton from the central Pacific: implication for paleoceanography. In Thiede, J., Vallier, T.L., et al., Init. Repts. DSDP, 62: Washington (U.S. Govt. Printing Office), $471-489$.

Sager, W.W., Winterer, E.L., Firth, J.V., et al., 1993. Proc. ODP, Init. Repts., 143: College Station, TX (Ocean Drilling Program).

Schaub, H., 1981. Nummulites et Assilines de la Téthys paléogène: taxinomie, phylogenèse et biostratigraphie. Schweiz. Palaeontol. Abh., 104-106.

Schlanger, S.O., Campbell, J.F., and Jackson, M.W., 1987. Post-Eocene subsidence of the Marshall Islands recorded by drowned atolls on Harrie and Sylvania guyots. In Keating, B.H., Fryer, P., Batiza, R., and Boehlert, G.W. (Eds.), Seamounts, Islands, and Atolls. Geophys. Monogr., Am. Geophys. Union, 43:165-174.

Schlanger, S.O., Jenkyns, H.C., and Premoli Silva, I., 1981. Volcanism and vertical tectonics in the Pacific Basin related to global Cretaceous transgressions. Earth Planet. Sci. Lett., 52:435-449.

Schlanger, S.O., and Premoli Silva, I., 1981. Tectonic, volcanic, and paleogeographic implications of redeposited reef faunas of Late Cretaceous and Tertiary age from the Nauru Basin and the Line Islands. In Larson, R.L., Schlanger, S.O., et al., Init. Repts. DSDP, 61: Washington (U.S. Govt. Printing Office), 817-827.

Shiba, M., 1988. Geohistory of the Daiichi-Kashima seamount and the Middle Cretaceous eustacy. Sci. Rep. Nat. Hist. Mus., Tokai Univ., 2:1-69.

Skelton, P.W., 1988. The trans-Pacific spread of equatorial shallow-marine benthos in the Cretaceous. In Audley-Charles, M., and Hallam, A. (Eds.), Gondwana and Tethys. Geol. Soc. Spec. Publ. London, 37:247-253.

Skelton, P.W., and Wright, V.P., 1987. A Caribbean rudist bivalve in Oman: island-hopping across the Pacific in the Late Cretaceous. Palaeontology, 30:505-529.

Swinburne, N.H.M., and Masse, J.-P., 1995. Early Cretaceous rudist fauna of Allison and Resolution guyots, Mid-Pacific Mountains. In Winterer, E.L., Sager, W.W., Firth, J.V., and Sinton, J.M. (Eds.), Proc. ODP, Sci. Results, 143: College Station, TX (Ocean Drilling Program), 5-16.

van Gorsel, J.J., 1978. Late Cretaceous orbitoidal foraminifera. In Hedley, R.H., and Adams, C.G. (Eds.), Foraminifera (Vol. 3): London (Academic Press), 1-120.

Date of initial receipt: 2 August 1994

Date of acceptance: 23 December 1994

Ms 144SR-015

\section{APPENDIX}

List of Preliminary Identifications of Corals from Leg 144 (by Ann F. Budd)

\section{Site 878, MIT Guyot}

Lithologic Unit II (Albian to ?Aptian):

Sample 144-878A-18R-1, 29-31 cm: solitary, cast of base, number of costae $=22$, corallite diameter $(\mathrm{cd})=55 \mathrm{~mm}$, strong synapticulae

Genus: ???Axosmilia or Trochosmilia

Range and geographic distribution: Jurassic-Cretaceous; Europe, Africa, Texas

Sample 144-878A-31M-1, 20-22 cm: solitary, worn surface of calice, $c d=12$ $\mathrm{mm}$, number of septa $(\mathrm{ns})=12$, distinctive septal arrangement, thick septa, lamellar columella

Genus: ???Tiarasmilia or Adkinsella

Range and geographic distribution: early Cretaceous; Texas

\section{Lithologic Unit V (early Aptian):}

Sample 144-878A-73R-1, 9-13 cm (thin section): thick, vesicular wall, corallites in clusters, $c d=5 \mathrm{~mm}, \mathrm{~ns}>12$, recrystallized

Genus: ??Mitrodendron

Range and geographic distribution: Jurassic-Cretaceous; Europe

Sample 144-878A-73R-1, 23-25 cm: cast, intratentacular budding, $c d=3-4$ $\mathrm{mm}$ ( $\mathrm{min})$, plocoid, synapticulae

Genus: ?Ovalastrea

Range and geographic distribution: Jurassic-Cretaceous; Europe, Africa, Asia, West Indies, Texas

Sample 144-878A-73R-1, 49-52 cm (thin section): cerioid, strong wall, intratentacular budding, $\mathrm{ns}=20-30, \mathrm{~cd}=3.3 \mathrm{~mm}$

Genus: ?Isastrea

Range and geographic distribution: Jurassic-Cretaceous; Europe, Africa, Texas

Sample 144-878A-76R-1, 69-73 cm (thin section): cerioid or plocoid, ??synapticulae, strong columella, $\mathrm{ns}=12, \mathrm{~cd}=1.2 \mathrm{~mm}$

Genus: ??Heliocoenia

Range and geographic distribution: Jurassic-Cretaceous; Europe

Sample 144-878A-76R-1, 100-106 cm (thin section): plocoid, strong columella, $\mathrm{ns}=24, \mathrm{~cd}=1.5 \mathrm{~mm}$, extensive coenosteum with synapticulae

Genus: ?Actinacis

Range and geographic distribution: Cretaceous-Oligocene; Europe, North America, West Indies, East Indies, Africa

Sample 144-878A-76R-1, 106-111 cm (thin section): plocoid, strong columella, $\mathrm{ns}=12, \mathrm{~cd}=1.5 \mathrm{~mm}$, extensive coenosteum with synapticulae

Genus: ?Actinacis

Range and geographic distribution: Cretaceous-Oligocene; Europe, North America, West Indies, East Indies, Africa

\section{Site 879, Takuyo-Daisan Guyot (late Albian to Aptian)}

Sample 144-879A-2R-2, 35-45 cm (thin section): cerioid to plocoid, trabecular columella, $\mathrm{ns}=24, \mathrm{~cd}=1.2 \mathrm{~mm}$

Genus: ???Montastraea or Columnocoenia

Range and geographic distribution: Jurassic-Holocene; Europe, West Indies, Texas, Indo-Pacific

Sample 144-879A-10R-1, 0-6 cm (thin section):

A: cerioid, $\mathrm{cd}=4 \mathrm{~mm}, \mathrm{~ns}=30-40$

Genus: ?Siderastrea

Range and geographic distribution: Cretaceous-Holocene; Europe, West Indies, North America, Indo-Pacific

B: plocoid, $\mathrm{ns}=30, \mathrm{~cd}=2 \mathrm{~mm}$

Genus: ?Diploastrea

Range and geographic distribution: Cretaceous-Holocene; Europe, West Indies, North America, Indo-Pacific

$\mathrm{C}$

Genus: ?Actinacis

Range and geographic distribution: Cretaceous-Oligocene; Europe, North America, West Indies, East Indies, Africa

List of Rudists from Sites 874 and 877, Wodejebato Guyot (by Gilbert F. Camoin and Jean Philip in Camoin et al., this volume)

Radiolitids: Distefanella mooretownensis, Distefanella sp.

Plagioptychids: Mitrocaprina sp., Coralliochama orcutti, Coralliochama sp., Plagioptychus aff. fragilis, $P$. aff. minor

Antillocaprinids: Antillocaprina sp.

Occurrence. Campanian-Maastrichtian strata from Jamaica, Mexico, Cuba, and California. 